UDK: 316.66-055.2:82

821.163.42.09-31 Božić, $M$.

Izvorni znanstveni članak

Primljen 17. VI. 2019.

Mirela ŠuŠIĆ

Sveučilište u Zadru, Odjel za kroatistiku

msusic@unizd.hr

\title{
SNAGA NEMOĆI KNJIŽEVNOGA LIKA KAO AFIRMACIJA AUTOROVA ZNAČENJSKOG SUSTAVA
}

\section{Sažetak}

Uspjelost karakterizacije ženskih urbanih likova u Božićevim kurlanskim romanima doticana je tek usput, u svrhu interpretacije ostalih strukturnih elementa romana ili pak Božićeve poetike, a spominjani su kao stereotipni i konvencionalni. Međutim, Ada Zrnićeva, Božićev urbani ženski lik, na koju je usmjereno proučavanje u ovome radu, izgrađena je, štoviše zaokružena osobnost koja djeluje autonomno kao samostalna ličnost upravo zahvaljujući umješnim Božićevim književnim postupcima u oblikovanju karaktera. Božić ulazi u emocionalno-psihološki svijet, imaginativne, etičke, vjerske, socijalne i druge predjele junakinje, a naratološkim postupcima kojima stvara ovaj ženski lik u svome pripovjednom univerzumu zapravo odgovara na ključna egzistencijalna pitanja.

Ključne riječi: ženski lik; karakterizacija; urbano; konotacija; značenjski sustav 
Trilogija o Kurlanima ${ }^{1}$ velikim dijelom tematski je usmjerena na položaj i ulogu žene u obitelji, ali i u širem socijalnom okruženju u kojem je žena najčešće prikazana kao objekt pripadajućega prostora i kao odraz patrijarhalnoga stanja društva koje ženu promatra isključivo kroz njezinu ulogu u majčinstvu i u kućanstvu. Međutim, proučavajući ženske likove u Trilogiji kao jedinstvenome djelu, a polazeći od njihova središnjeg doživljaja čiji je ishod u poetskome bogatstvu Božićeva osebujna, sugestivna jezika, uočava se specifičnost Božićeve poetike žene iz koje proistječu glavne protagonistice kao dignitetni likovi i to - ako ne u svim segmentima svoje ličnosti, onda svakako u pojedinačnim, ali vrlo upečatljivim sekvencama svoje osobnosti.

Istražujući književnu kritiku koja se bavila dijelom ili pak Trilogijom o Kurlanima u cijelosti, uočilo se kako su urbani ženski likovi ostali zapostavljeni, gotovo nespomenuti, a ako je i bilo kakvih osvrta poput članka Nade Barac u kojem se ona bavi romanima Kurlani i Neisplakani, onda bi se njezina kratka ocjena uspjelosti karakterizacije urbanih likova poput lika Zrnića i Kalkića, uz koje se tek usput spominje i Adu Zrnićevu, mogla svesti na konstataciju o „blijedim“, „konvencionalnim“, „stereotipnim“ likovima. ${ }^{2}$ Međutim, relevantan prinos Božićevim urbanim likovima, ponirući dublje u njihove duhovne vitrine i ulazeći u bitnome $u$ njihove strukturne sadržaje, daje Šimun Musa baveći se urbanom tematikom u Božićevoj novelistici i njezinim jezično-stilskim značajkama. ${ }^{3}$

O urbanim ženskim likovima Božićeve Trilogije susreću se i oprečna mišljenja. Tako će Nada Barac, baveći se prvim dvama romanima Trilogije, romanom Kurlani i romanom Neisplakani, između ostaloga, lik Ade Zrnićeve okarakterizirati kao nemotiviran lik koji: „stereotipno

Trilogija o Kurlanima sastoji se od romana Kurlani, gornji i donji (1952.), Neisplakani (1955.) i Tijela i duhovi (1981.). Fabulativno su različiti, ali su semantički povezani te ih prema Vlatku Pavletiću, kako on to navodi u svojoj knjizi Kurlanski bijesni čvor: trajni književni domet Mirka Božića iz 2006. godine, valja proučavati kao jedinstveno, cjelovito djelo. Zbog toga se sintagma „kurlanska trilogija“ piše velikim početnim slovom kao Trilogija o Kurlanima. Naime, sva se tri romana istražuju kao jedinstveno djelo koje kao takvo premašuje vrijednost svojih zasebnih dijelova.

2 Usp. NadA BARAC, „Dva romana Mirka Božića“, Krugovi, Zagreb, br. 6-7, 2003., str. 246.

3 Usp. Šimun Musa, „Urbana tematika u novelistici Mirka Božića i njezine jezično-stilske značajke“, Riječ, Rijeka, god. XIII. (2007.) br. 2., str. 160-168. 
pada u nesvjesticu i još se stereotipnije ubija, a da nam pri tom uopće nije jasno, da to čini zato što mora, što je njena vlastita krv vodi na to. Naprotiv, skoro je očito da se sve to dešava zato, što je piscu bio potreban i jedan takav lik, da upotpuni galeriju konvencionalnih gradskih malograđanskih likova“"

S drugu će pak stranu Vlatko Pavletić istaknuti kako Ada nije plosnat lik koji se lako previdi odnosno nakon čitanja brzo zaboravis ${ }^{5}$ a što će se afirmirati i ovim radom. Dakle, iako Nada Barac općenito drži kako su Božićevi urbani likovi, poput navedene dvojice advokata, „klišeji, koji ne djeluju kao žive ličnosti“", pokazat će se kako je Božićev lik Ade Zrnićeve, na koju je usmjereno proučavanje u ovome radu, izgrađena, štoviše zaokružena osobnost koja kao književni lik u autorovu značenjskom sustavu, čija je okosnica konotativna poetska snaga sugestije, upravo snagom nemoći djeluje autonomno kao samostalna ličnost. Junakinja samosvjesno, vlastitim mislima: Treba moći htjeti!n ovjerava autonomnost vlastite pozicije i snagu Božićeve specifične karakterizacije.

Iako će za lik Ade Nada Barac kritički ustvrditi kako je nemotiviran lik za koji je dobila dojam da se donekle „otrgla od piščeve volje samo onda kad je u šetnji s izaslanikom seljačke stranke zaželjela, da se malo prosanjka. To je jedina njena vlastita želja. Sve ostale želje i željice nametnuo joj je pisac" ${ }^{\text {, }}$ pomnim proučavanjem ovoga urbanog ženskog lika doći će se do posve drugačijih zaključaka.

Naime, sveznajući pripovjedač predstavlja Adu Zrnićevu osvjetljavajući njezin socijalni položaj i okolnosti u kojima je živjela te prikazuje slike njezina odrastanja, utjecaja i iskustava integriranih u njezinu osobnost, a što piscu služi i kao motivacijski sustav njezinih stanja i ponašanja koja će uslijediti:

\footnotetext{
N. BARAC, $n$. $d j$., str. 246.

Usp. Vlatko Pavletić, „Pogovor“, Mirko Božıć, Tijela i duhovi, Nakladni zavod Matice hrvatske, Zagreb, 1989., str. 318.

$6 \quad$ N. BARAC, $n$. dj., str. 246.

Mirko Božıć, Neisplakani, Nakladni zavod Matice hrvatske, Zagreb, 1989., str. 81.

$8 \quad$ N. BARAC, $n$. dj., str. 246.
} 
Bila je kćerka pokojnog notara Kalkića koji je Frani i njoj osigurao življenje ostavivši im stare kuće i veliko imanje. Ništa joj nije i ne bi falilo, ništa, sva mladost bila joj je sretna, iako skromna i stroga. (Trenutačno je trajao pokoji stisak kavalerijskih oficira na saonicama; iščezli su 1917-te; srpski oficiri, koji su „konje pojili morem", tresnuli su joj na prvom balu u čast oslobodenja takvu bezobraštinu, zapravo udivljenje „njenim belim grudima koje sunce ne greje za razliku od njihovih crnih $i$ debelih kao opanak muda koje također sunce ne greje", da se sva zažarena smjesta udaljila; zaključila je jednom zauvijek da su svi oficiri glupi „samim tim što nose dugačke sablje.) Mladost sretna, skromna i stroga dok nije došao on. Tu večer skandirala je: Vjeko, Vjeko, Vjeko... Mlad je bio i nasrtljiv, mnogo nasrtljiv, nikad nije znala bi li se žarila od stida ili radosti, dok se nije sve skupa izmetnulo u bračni čvor. Mnogo je puta ona zbog njega plakala, toliko mnogo da se jedva prisjećala kako ga je na vjenčanju tek nešto malko ljubila. Potpuno neidilički život vukao se ravno i bez skretanja, a „od onda" postajo sve više $i$ više mučilište. „Od onda" je birala samo stare sluškinje. Znala je, ta živo je stvorenje, da se i Zrnić, kao i ostali zadrigli gradani, koprca svojim alatom u hlačama $i$ da naslonjen na lijevi blok kuća uz pijacu promatra svakovečernje komešanje $i$ bujanje mladosti; oblizivao se i on za poletaricama-gimnazijalkama, mladim sluškinjama i seljankama ...9

Ada postaje nesretna tek ušavši u brak. Uzrok je svih njezinih jada muževo zanemarivanje koje autor naglašeno sugerira „od onda“, dakle od trenutka koji ne eksplicira, ali insinuira. Jasno navodi na misao o Zrnićevu preljubu koji je u bitnome obilježio Adino unutarnje stanje i općenito nezadovoljstvo vlastitim načinom života. Dakle, ona je kći ugledna građanina, materijalno situirana. U pretpostavljenome redu i skladu udaje se za muškarca koji „do nje ne drži“, slijedom čega se u njoj razvija kompleks manje vrijednosti koji ona konstantno pokušava zatomiti pridodajući sama sebi osjećaj „veće vrijednosti“. U sustavu njezinih vrijednosti „veća vrijednost“ bila bi život u velegradu:

Adine kuće otkupit će, nudeći joj malo-pomalo, na rate, sredstva kojima će ona ostvariti ono za čim čezne: moderan stan u Zagrebu i banalnu opersku atmosferu. Moći će kupiti i bösendorfer na kojem će metalnije $i$ tužnije zvučati njena "ritorna" ..."

\footnotetext{
9 Mirko Božić, Kurlani, Nakladni zavod Matice hrvatske, Zagreb, 1980., str. 101.

10 Isto, str. 151.
} 
Njezino stremljenje velegradskomu životu i ljepoti samo je pokušaj zatomljenja svega što je u njezinu životu ružno, a osjećaj ružnoga nastaje iz suprugova odnosa prema njoj u kojem se očituju njegova grubost, omalovažavanje i apsolutni izostanak pozitivnih emocija:

Zašto je uvrijedio šjor Mirka, zašto? ponavljala je u sebi i odmah munje-
vito odgovarala: samo da mene uvrijedi, mene! Sad se već privikavala
njegovim vrijedanjima. Privikavala? Uvrijedio je šjor Mirka, čovjek
umalo nije zaplakao. Kao da mu je slušala druge riječi u onom; „Ma daj,
prihvati im, 'Okarina'!“ To je bilo upućeno njoj: „Glupačo, ovaj ti lutkan
'falsetom' izvija zanosne arije i ti misliš da si negdje u svijetu, u blistavim
baroknim gledalištima punim dekoltiranih dama i gospode u crnom; a
gledaj njegovu kravatu, njegov nasmiješeni ushit u vodenim plavozelenim
očima, ushit varoškog harlekina i cirkusijanta, ti si smiješna a ne on, ti
si glupa a ne on, ti si staromodna a ne on ... Ti govoriš da on ima 'vedru
prirodu' i ti se čudiš kako se s takvom prirodom 'ne udeblja'. Ti misliš da
njegov smijeh nije glup i pravdaš to što 'on pjeva' a 'tko pjeva, zlo ne misli'. Glupačo, po sto puta glupačo ${ }^{11} \ldots^{12}$

Kroz Adin unutarnji monolog spoznaje se nesklad vremenski dužih i psihološko dubljih bračnih razmirica i nagovještava se njezin osjećaj usamljenosti. Osim brata, čiju pažnju zaokuplja samo zbog materijalnih mu interesa, i to od onog dana kad se Ada, nakon uzastopnih Zrnićevih zahtjeva, imovno odijelila od njega ${ }^{13}$, nema nikoga svoga. Tako je bratovo posjećivanje ovoga dobrostojećeg malovaroškog bračnog para bez djece u takozvanim „ohoho“ godinama ${ }^{14}$ motivirano isključivo njegovim interesima, ali ne i stvarnom, iskrenom bratskom ljubavlju i brigom za nesretnu sestru. Štoviše, njegovi su postupci dugoročno unaprijed isplanirani, pragmatični i materijalno proračunati, a Ada mu služi samo kao sredstvo kojim će ostvariti svoj cilj:

Zrnić mora da se kandidira, da odvede Adu u Zagreb i da se više ne vraća u ovu varoš u koju je kao uljez došao. Propagirajući Zrnića, on će $u$ isto vrijeme pripravljati $i$ teren sebi kod onih gore u Zagrebu. Adine

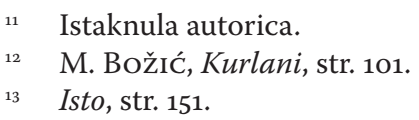


kuće otkupit će, nudeći joj malo-pomalo, na rate, sredstva kojima će ona ostvariti ono za čim čezne... ${ }^{15}$

Dakle, Ada je i sama i usamljena, a jedinu naklonost koju osjeća je ona suprugova pisara Okarina, malograđanina:

Nije mu laskala stoga što je kao „umjetnik“svirao u drugu klarinetu mjesne sokolske glazbe nego više da mu se oduži za dobrovoljno skakanje poput slugana-vrapčića po ovu ili onu stvar koju bi ona zaželjela. ${ }^{16}$

Međutim, s obzirom na negativnu etičku karakterizaciju lika Okarine, ovjerenu njegovim aktivnim angažmanom oko Berlešina grotesknog vjenčanja s Perom, sluškinjom Adina brata Frane Kalkića, ni ova naklonost nema afirmativnu emocionalnu vrijednost jer dolazi od „nevrijednog" lika:

Ada se naprosto sramila. I zbog sebe i zbog svih. Znala je za smišljenu saturnaliju, koja se pripremala ovih dana sa strašću dosadnika, u kojoj je Pera, trebala igrati ulogu slijepe žrtve. Najprije sužanj sebe, a onda sužanj svih. I ako se to ne želi, ako se to neće, ako se hoće ostati neublaćena... onda omalovažavanje, prezir. Zar je, evo, muž ne savjetuje omalovažavajućim pogledom, da se spusti na niže, na zemlju, u varoš, gdje joj je mjesto, gdje je preživjela "svoje" i gdje treba biti vjeran i dosljedan svome. U stvari je tako. Čime, kako zamijeniti ovo? „Suzi zaslon svoje lude leće, naš svijet je slijep samo kroz obično staklo; a čiji je to svijet lijep pod lupom? Budalo fanatizirana, uobražena plemkinjo, žalosti moja! ${ }^{17 " ~}$ - odašiljali su njegovi daškovi, $i$ ona se uzaludno trudila da slušno ukopča kakve druge šumove. ${ }^{18}$

Božićevo „pitanje smisla postojanja uopće ${ }^{{ }_{119}}$ ogleda se ponajviše u ovome ženskom liku, obogaćenu mogućnošću spoznavanja pojava u njihovu pozitivnom i negativnom kontekstu. Međutim, iako društveno

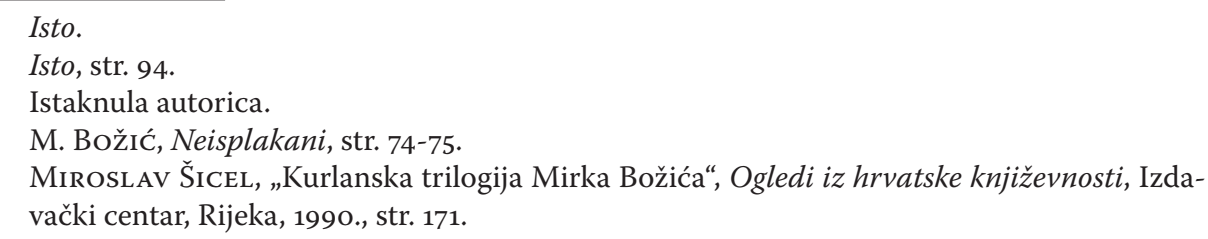


osviještena i s razvijenim moralnim kodeksom, Ada ništa ne poduzima kako bi se postojeće stanje stvari izmijenilo. Njezina nemoć djelovanja sputana je odbojnošću koju „njeguje“: ...nije mogla da ogrubi, da se oprostači, jer su je grubostima i prostaštvom zasipali dnevno, a ona je osjetila, da im se može osvetiti, vječno osvećivati, jedino svojim ufinjenim odbojnim mukom, kao čudna biljka. ${ }^{20}$

Ovaj ženski lik ne ovjerava svoj karakter u ostvarenju bilo koje od svojih želja, ne ozbiljuje se u zadanoj životnoj stvarnosti:

...nije zapravo nikad ni ispunjavala svoje želje. Ona bi samo zaželjela $i$ na tome bi ostalo. Onda bi još želja zaželjela da $i$ one uginu jalove, $u$ neispunjenju. To nije bilo ono trošenje vremena $i$ boja - što bi bila sreća - nego neispunjene ljudske svrhe uopće.21 Učini joj se sad, da je nešto krupno izmislila - valjda pod utiskom i utjecajem doktorova uma. ${ }^{22}$

Međutim, Ada nije ispunila svoju svrhu niti je u bilo čemu ostvarena. Ona je „žena u godinama“, bez djece i bračne sreće, nema prijatelja, dakle jedina joj je svrha biti Zrnićeva žena, a upravo kao žena u elementarnome smislu nije ostvarena jer vlastitomu suprugu nije poželjna:

Jutros, vrlo rano, oko sedme ure, probudio se Vjekoslav Zrnić i Ada ga je htjela radosno poljubiti kao na veliki datum „našeg života", ali ju je on oneraspoložio povikavši:

- Kavu!... Čovjek je na iglama, a ona bi se... Ah!

- Bože moj, nesretna li sam?! - poleti ona plačno i tužno u kuhinju.

Ali je ipak nastojala svim svojim bićem da "stvar" razumije, to jest, "nervozu“ $i$ „ono ostalo“. Brižljivo je, kao dobra službenica, složila po krevetu muževo odijelo i nijemo ga bodrila „svojim posluhom". Ali, kad ga je htjela zbilja raspoložiti da izađe „slobodna daha", ispostavilo se opet da „ona nema načina", „da je svadljive prirode“, da ne umije „ugoditi čovjeku“ i da "ne razumije ništa".

- Vjeko - rekla je umiljato - kad pobijediš, oćeš li me povesti u Zagreb?

$\begin{array}{ll}{ }_{20} & \text { M. Božıć, Neisplakani, str. } 82 . \\ { }^{21} & \text { Istaknula autorica. } \\ 22 & \text { M. Božıć, Neisplakani, str. 8o. }\end{array}$ 
- Dosta mi je što živim s tobom i ovdje! - uzvrati Zrnić, kao kakav Quirit zabaci balonac preko ramena i sleti niza stepenice pljunuvši na taj jutarnji prijedlog svoje žene $e^{23} .24$

Ovaj jutarnji prijedlog njegove žene nije bio sve na što je Zrnić „pljunuo“. Svojim grubim nerazumijevanjem, odnosno pomanjkanjem volje da bilo što razumije kod Ade, apsolutnim izostankom osjećaja prema njezinim emocionalnim, fizičkim i duhovnim potrebama, Zrnić je pridonosio razvoju pitanja smisla njezina bitka, njezina postojanja uopće, koje će kasnije odrediti Adin kraj.

Zarobljena zabludnim uvjerenjem da će promjenom životne okoline promijeniti svoje unutarnje stanje i osjećanje, ostaje u „čekanju“ koje je za nju stalno stanje: [...] ali istodobno je prožme žalostan osjećaj „divljine", u kojoj je prisiljena da živi. ${ }^{25}$

Jedina akcija koju poduzima ostvarena je kroz klimaks ovoga ženskog lika, a on će prethoditi njezinu kraju. Susret Ade i povjerenika, u kojem ona nakon dugo vremena osjeća da je žena, nije potenciran poslanikovom angažmanom, već Adinom percepcijom stvari:

Ada Zrnić (promatra izaslanika) osjeti na sebi mutni bljesak njegovih sivih smirenih očiju, kao u starog lava. Motrila je pod trepavicama, neopazice, kroz mrenu, njegovu četvrtastu snažnu glavu obraslu čekinjastom prosijedom kosom. Beethoven, pomisli, kao Beethovenova bista. Nešto trajno, umno, lijepo. Metalni plemeniti sjaj i zvuk. Protrne od čuvstva već zaboravljene slasti. Kao da joj je netko silno mio pogladio sapi. ${ }^{26}$

Gledala ga je s udivljenom ljubaznošću, razumijevajući i opravdavajući njegovu velegradsku tihu snishodljivost. Nove riječi i nova muzika riječi, njihov posebni, meki profinjen "jesenski" naglasak, trgnuli su je iz misaone otuplosti, и koju je zapala u krugu istih navika, vječno u sebi zarobljena svojim žalopojkama, koje, i da ih je povjerila, nitko

\footnotetext{
${ }^{23}$ Istaknula autorica.

24 M. Božić, Kurlani, str. 204.

25 M. Božıć, Neisplakani, str. 71.

26 Isto, str. 69.
} 
ne bi mogao shvatiti. ${ }^{27}$ Sad je taj čovjek, njegov bezbrižni ton, skladni govor, pun neke skrivene snage, budio u njoj pokopanu nadu, skromnu želju da se dovine grada, opere ... Je li to glazba, miris, nagovještaj, možda motiv njene nade?! Ah! Val žudnje plahne, ruka joj zadrhti. Trepne. ${ }^{28}$

Koristeći se posrednom karakterizacijom, pisac refleksijom lika Ade u očima njezina brata, koji je promatra dok s izaslanikom odlazi prema klizalištu, eksplicira njezin fizički izgled i pri tome konotira zagušeno ženstvo, istovremeno implicirajući motiv menopauze. Na taj način nagovještava njezin višeznačni zalazak kroz približavanje kraja njezine reproduktivne dobi:

Obukla je danas, poslije toliko godina, plavu haljinu od samta, prikopčala mamine krupne biserne naušnice (mladenačko sjećanje!) $i$ nacrvenila žutoliko lice, kao fini pijesak. Gle, i oči su joj dobile trunak sjaja, kao ove rozete, jutros ulaštene, na ovom njegovom altdojč pokućstvu. Velikoj je mijeni na domaku ako već nije odavno u njoj. ${ }^{29}$

Adina „autsajderska“ pozicija nije nametnuta, već je svjesno odabrana jer ona svojom „profinjenom odbojnošću“ upravlja vlastitom voljom i u željenome smjeru. Međutim, njezina nemogućnost afirmacije u vlastitome braku, kao jedinoj i posljednjoj oazi, u kojem bi trebala ostvariti svoju osobnost i ovjeru identiteta, mjesto je na kojem nakon duga „krpanja" pucaju Adine mentalne spone:

„'Krpanje' zarida ona sebi 'ono jadovno duševno krpanje, 'Krpanje. Zakrpa na zakrpi. I suza na suzi, ali nataložena negdje, duboko. Jezero suza u nama grgolji i struji, ali pri 'krpanju' neće da kane ni jedna jedincata. A kapaju sigurno, kapaju - ali gdje? Možda se iskristaliziraju kao ledene kapnice. Zaludu ih pokušavam odlediti. Trne to, trne, ledi se. Adio, adio!"3o

\footnotetext{
27 Istaknula autorica.

${ }_{28}$ M. Božı́́, Neisplakani, str. 70.

29 Isto, str. 80.

3о Isto, str. 153 .
} 
Metežni refleks njenog „primoranog“ bivstva ${ }^{31}$ zakovitlat će se u svoj svojoj snazi neposredno nakon Adine i Zrnićeve žučne rasprave oko njezina kasnog izlaska, motivirana njezinim konstantnim osjećajem samoće, zbog čega je i izišla potražiti muža. Komentirajući suprugovo društvo i razinu zabave koja ga uveseljava i izaziva mu smijeh, Ada motivira Zrnićevu nepromišljenu i bezdušnu poredbu koja mu nesmotreno izlijeće o nužnosti ružnoga smijeha s ružnom ženom: nuždan... i ružan... kao vlastita žena ${ }^{32}$. Ova Zrnićeva neukusna i za Adu dubokoznačna i dalekosežna poredba koju Zrnić iznosi, bez dovoljno ljutine da bi se moglo opravdati afektom, zazvučala je u Adinoj nutrini kao svjesna, promišljena konstatacija njezine nazočnosti u njegovu životu i zadobila je maha koji je doveo u pitanje relevantnost Adina prisustva u životu uopće. Rodilo se pitanje smisla njezine egzistencije.

Koliko god se ovaj Božićev ženski lik književnoj kritici činio nezanimljiv i stereotipan i koliko god smatrali da je nastao samo zato „što je piscu bio potreban i jedan takav lik" ${ }^{\text {"33 }}$, upravo se u njemu i na ovome mjestu Trilogije o Kurlanima ogleda izuzetna Božićeva poetska snaga konotacije i specifičnost njegova značenjskog sustava. Naime, piščevo indirektno sugeriranje potresenosti koju Ada doživljava u trenutku ove Zrnićeve izjave, odnosno „kap koja je prelila njezinu čašu“, godinama punjenu Zrnićevim uvredama i omalovažavanjem, što verbalno izrečenim, što mimikom pokazanim, a govorom tijela naglašenim, jasno dolazi do izražaja u stilski obojenoj rečeničnoj konstrukciji: Ote joj se u dubini duše samoubilački krik. ${ }^{34}$

Autonomnost lika odvjetnika Zrnića jedino na ovome mjestu događanja dolazi do izražaja jer se oteo volji pisca odskačući od paradigme dosadašnjih ponašanja. Naime, Zrnić je osjetio „da je prešao granicu“ pa se, a što bitno odstupa od svih njegovih dotadašnjih ponašanja i stanja, čak malo primirio pokušavši to "ružna žena“ ispraviti. Međutim, bilo je kasno. Adi je već počelo „strujati glavom“ te započinje njezin

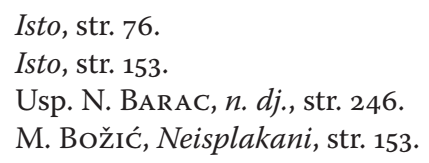


neočekivani smijeh kao izraz gorčine: Smijeh je sada odzvanjao kao iz glinene kutije, kao iz podruma samoga pakla, mrvio se i rasipao na zatajene i sve tiše jecaje kao da je postajao prah sušnih suza. ${ }^{35}$

Samosvjesna kada misli: Treba moći htjeti ${ }^{36}$, ali nemoćna za djelovanje, Ada je počinila samoubojstvo, a Zrnić je toliko hladan na ovaj događaj da ni sam ne može vjerovati:

Nije moguće da je ovako bezosjetan, da ovako precizno misli i gleda, nije moguće. Što navire sad u njemu, što? Neka vrsta spasonosne praznine? ${ }^{37}$ Trebalo bi pred njima... što? Malko glumiti? Ada! Ada! Neka ponavlja to ime, možda će ga ganuti. Ada! Skromno, vrlo skromno, skriveno dobro u njemu, mora da postoji. Je li, postoji li? Skromno, vrlo skromno, vrlo skromno i stidno dobro. I vječno prisutni strah. ${ }^{88}$

Portretom Ade može se zaključiti i njezina karakterizacija:

S vrha pijace, po kamenom trotoaru koračala im je u susret visoka vitka žena. Zvonko su kuckale njene Louis Quinze-potpetice, na kojima je tepljala kao da joj se tanke noge lome u gležnjevima. Pridržavala je lijevom rukom obod fiorentinskog šešira $i$ sklanjala pod njegovo slabašno okrilje glavu pred zamasima vjetra. Zastajkivala je, dok bi joj vjetar pripijao suknju uz mršave obrise, i mrsila zatim hod. Približavala im se nekako svečano-ponosno, a opet skanjivo, nesigurno kao neka samotna sudenica $^{39}{ }^{40}$

I uistinu se ova ponosna, ali nesigurna žena skanjivala svakoga djelovanja i sama je sebe žudnjom za "svečanošću“ osudila na samotno životarenje. Temeljne karakteristike ovoga ženskog lika odražavaju se u njezinim odnosima, a ostvarene su tehnikama dijaloga i monologa. Njezin odnos prema Okarini proizlazi iz sažaljenja. Sva njezina nesreća proizlazi iz neskladna odnosa sa suprugom što je egzistencijalno određuje, a dodatni izvor njihova neskladna braka ostvaren je upravo

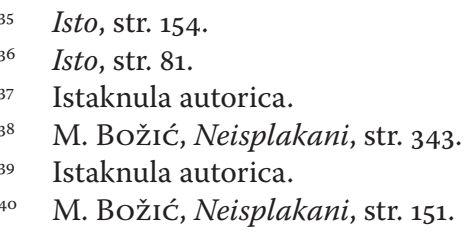


tehnikom dijaloga koji konotira dva suprotstavljena diskursa od kojih jedan, onaj Zrnićev, unaprijed želi ostati nerazumljiv i ne želi razumjeti. Tehnikom dijaloga Ada izražava svoja stremljenja prema drugačijemu životu i svijetu, a unutarnjim monologom pisac odražava opće duhovno stanje ovoga književnog lika.

Božićevo shvaćanje ženskoga lika temelji se na shvaćanju ontološkoga polariteta muškarca i žene kao bogatstva u različitosti koje ih stalno upravlja jedno prema drugomu, a čiji se identiteti, i muški i ženski, definiraju tom vezom. Beznadnost Adina položaja i njezina snaga nemoći, bez pomoći metaforičke interpretacije i semantike simbola, mogle bi se krivo tumačiti kao statičnost lika koji nije reljefno izgrađen. Međutim, lik Ade pravo značenje zadobiva u kontekstu osnovnih egzistencijalnih pitanja bitka afirmirajući autorov značenjski sustav.

\section{Literatura}

- Barac, NadA, „Dva romana Mirka Božića“, Krugovi, Zagreb, br. 6-7, 2003., str. 243-257.

- Božıć, Mırкo, Kuralni, Nakladni zavod Matice hrvatske, Zagreb, 1980.

- Božıć, Mırko, Neisplakani, Nakladni zavod Matice hrvatske, Zagreb, 1989.

- Božıć, Mirko, Tijela i duhovi, Nakladni zavod Matice hrvatske, Zagreb, 1989.

- Musa, ŠImun, „Urbana tematika u novelistici Mirka Božića i njezine jezično-stilske značajke“, Riječ, Rijeka, god. XIII. (2007.) br. 2., str. 16o-168.

- NemeC, Krešimir, „Čuvarica ognjišta, svetica, vamp. Slika žene u hrvatskoj književnosti 19. stoljeća“, Zbornik radova Zagrebačka slavistička škola 2002., BотіCA, STIPE (ur.), FF press, Zagreb, 2003, str. 100-108.

- Oraić Tolić, Dubravka, Muška moderna i ženska postmoderna, Naklada Ljevak, Zagreb, 2005. 
- Pavletić, Vlatko, Kurlanski bijesni čvor: trajni književni domet Mirka Božića, Matica hrvatska, Zagreb, 2006.

- Pavletić, Vlatko, Umijećem do umjetnosti, Školska knjiga, Zagreb, 2009.

- Pavletić, Vlatko, „Pogovor“, Božıć, Mirko, Tijela i duhovi, Nakladni zavod Matice hrvatske, Zagreb, 1989., str. 309-351.

- Peleš, GAJo, Iščitavanje značenja, Izdavački centar Rijeka, Rijeka, 1982.

- Solar, Milivoj, „Mit o ženskoj prirodi“, Edipova braća i sinovi, Golden marketing - Tehnička knjiga, Zagreb, 2008.

- ŠICEL, Miroslav, „Kurlanska trilogija Mirka Božića”, Ogledi iz hrvatske književnosti, Izdavački centar, Rijeka, 1990.

- VuČEtić, ŠIME, „Kurlanski roman Mirka Božića“, Ogledi o suvremenicima, Naprijed, Zagreb, 1988.

- Weininger, Отto, Spol i karakter: načelno istraživanje, Euroknjiga, Zagreb, 2008.

- Woolf, Virginia, Vlatita soba, Centar za ženske studije, Zagreb, 2003.

- ŽMegač, Viktor, Povijesna poetika romana, Matica hrvatska, Zagreb, 2004. 
Mirela ŠUŠić

University of Zadar, Department of Croatian Studies

\section{POWER OF THE WEAKNESS OF A LITERARY CHARACTER AS AFFIRMATION OF THE AUTHOR'S SEMANTIC SYSTEM}

\section{Abstract}

The success of the characterization of urban female characters in Bozic's Kurlani novels was touched upon only incidentally for the purpose of interpreting other structural elements of the novel or Bozic's poetics, and these characters were referred to as stereotypical and conventional. However, Ada Zrnic, Bozic's urban female character, on whom this study focuses, is mature, moreover, complete personality. She act autonomously as an independent individual precisely thanks to Bozic's skilful literary processes in shaping a character. Bozic enters into an emotional-psychological world, imaginative, ethical, religious, social and other realms of this heroin, and with the narratological processes which he uses to create the female character in his narrative universe, he answers, in fact, the vital existential questions.

Keywords: female character; characterization; urban; connotation; semantic system 